\section{ВЫСОКОМОЩНЫЕ ВОЛОКОННЫЕ ОБЪЕДИНИТЕЛИ}

\author{
H.В.Буров', n.burov@oessp.ru, \\ Дж. Лин², Jason.lin@lightcomm.com, \\ B.Б.Ромашова 1,3, vasyokjk@gmail.com, \\ v.romashova@oessp.ru
}

'ООО "ОЭС Специоставка", С-Пб, Россия; 2 LightComm Technology Co, Jia'an Industry Park, Xin'an Subdistrict, Shenzhen, Китай; ${ }^{3}$ Санкт-Петербургский Государственный Университет Аэрокосмического Приборостроения, С-Пб, Россия,

\section{Надежность сплавных волоконных компо- нентов в волоконно-оптических лазерных системах обеспечивает высокий уровень мощ- ности излучения. В статье описаны основные проблемы создания волоконных объедините- лей и методы их решения для минимизации энергетических потерь и сохранения качества пучка.}

\section{ВВЕДЕНИЕ}

Волоконные лазеры высокой мощности находят применение в самых разнообразных промышленных процессах: обработке материалов, маркировке деталей и изделий, резке и сварке. Благодаря высокому КПД и превосходному качеству его выходного луча в сочетании с компактной конструкцией волоконные лазеры обрели популярность.

В настоящее время существует два типа активного волокна - GTWave и DoubleClad. Структура волокна GTWave имеет световод с активной сердцевиной и световоды, предназначенные для распространения излучения накачки. Схема такого волокна изображена на рис.1.

Известно [1], что при использовании CTWave волокна удалось достичь излучения мощностью 5,2 кВт. Основным недостатком таких волокон является сложность ввода излучения накачки. Волокно имеет малое количество точек ввода и ограничивает подводимую мощность накачки ввиду высокой вероятности возгорания.

Наиболее популярными и востребованными на сегодняшний день являются волокна типа DoubleClad. Doubleclad волокно имеет две оболочки: первая обеспечивает распространение полезного излучения в сердцевине, вторая - распространение излучения накачки. Поперечный срез волокна с двойной оболочкой представлен на рис.2.

\section{HIGH-POWER}

\section{FIBER COMBINERS}

\author{
N.V.Burov', n.burov@oessp.ru, \\ J.Lin'2, Jason.lin@lightcomm.com, V.B. Romashova ${ }^{1,3}$, \\ vasyokjk@gmail.com,v.romashova@oessp.ru
}

"LLC "OES Spetspostavka", St. Petersburg, Russia; ${ }^{2}$ China, LightComm Technology Co, Jia'an Industry Park, Xin'an Subdistrict, Shenzhen, China,

${ }^{3}$ Saint-Petersburg, Saint-Petersburg State university of Aerospace Instrumentation, Saint-Petersburg, Russia

The reliability of fused fiber components in laser systems provides a high level of radiation power. The article describes the main problems of creating fiber combiners and methods for their solution to minimize energy losses and preserve beam quality.

\section{INTRODUCTION}

High power fiber lasers are used in various industrial processes: material processing, marking of parts and products, cutting and welding. Due to its high efficiency and excellent qualities of its outgoing beam in combination with the compact design, fiber lasers have gained popularity.

Currently, there are two types of active fiber GTWave and Doubleclad. The structure of the GTWave fiber has an optical fiber with an active core and optical fibers intended for the propagation of pump radiation. The scheme of such a fiber is illustrated in Fig. 1.

It is known [1] that by using GTWave fiber, it was possible to achieve the radiation power $5,2 \mathrm{~kW}$. The main disadvantage of such fibers is the difficulty in input the pump radiation. The fiber has a small number of input points and limits the input pumping power due to the high probability of ignition.

The most popular and demanding today are fibers like Doubleclad. Doubleclad fiber has two clads: the first provides the propagation of useful radiation in the core, the second - the propagation of pump radiation. The cross-section of a double-clad fiber is shown in Fig. 2.

From the literature it is known that at the manufacture of lasers with an output power of $10 \mathrm{~kW}$ [2], radiating in a few-mode regime, Doubleclad fibers are used. Considering the value of the fiber breakage threshold of $10 \mathrm{~W} / \mu \mathrm{m}^{2}$ we receive that the admissible diameter of the mode field must be at least $36 \mu \mathrm{m}$. Thus, [3] indicates that the fiber with a core 
Из литературных источников известно, что при изготовлении лазеров с выходной мощностью на уровне 10 кВт [2], излучающих в маломодовом режиме, использованы Doubleclad волокна. Учитывая величину порога разрушения волокна 10 Bт/мкм², получаем, что допустимый диаметр поля моды должен составлять не менее 36 мкм. Так в работе [3] указано, что в волокне с диаметром сердцевины 50 мкм и с числовой апертурой $\mathrm{NA}=0,06$ была достигнута мощность 8 кВт, при этом параметр $\mathrm{M}^{2}$ составлял примерно четыре единицы. Дальнейшее наращивание мощности требует увеличения диаметра сердцевины и приведет к переходу в многомодовый режим. В существующих волоконных лазерах мощностью выше 10 кВт используется оптоволоконное объединение излучения от нескольких лазеров. Результирующее излучение оказывается многомодовым, но соответствует требованиям промышленных станков по обработке материалов.

Если рассмотреть схему высокомощного лазера (рис.3), то можно увидеть, что основными элементами лазера являются оптоволоконные объединитель накачки, адаптеры поля моды, фильтры оболочки и волоконные наконечники.

При разработке оптоволоконных компонентов необходимо учитывать множество деталей, обеспечивающих надежную работу элементов в условиях высокой мощности излучения. Например, потери в компонентах, которые обычно считаются нормальными для телекоммуникационных применений, могут привести к разрушению высокомощной лазерной системы из-за сильного перегрева. Как правило, наиболее важным элементом мощного волоконного лазера является объединитель излучения накачки, обеспечивающий ввод излучения в волокно.

Данная статья посвящена одному из важнейших видов компонентов, используемых в волоконных лазерах, - волоконным объединителям, используемым в качестве элементной базы волоконных лазеров и усилителей. Волоконные объединители можно разделить на несколько типов:

- Объединители накачки структуры $\mathrm{N} \times 1$. Устройства данного типа объединяют несколько источников излучения накачки в одно волокно (рис.4).

- Объединители накачки с центральным сигнальным каналом структуры $(\mathrm{N}+1) \times 1$. Данные устройства объединяют несколько источников излучения накачки в одно волокно и дополнительно в центре имеют канал, в который подается сигнал для дальнейшего усиления (рис.5).

- Объединители мощных сигналов структуры $\mathrm{SN} \times 1$. Они предназначены для объединения

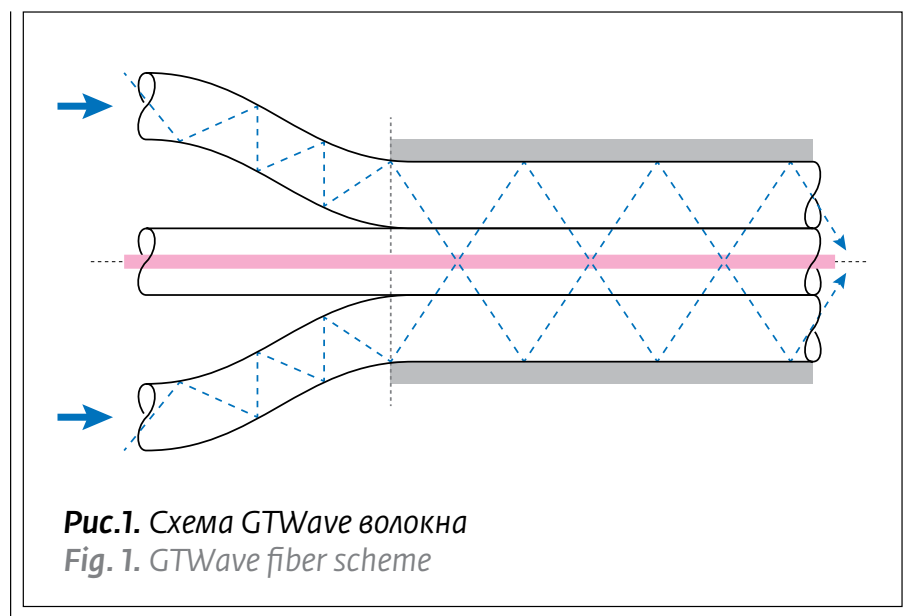

diameter of $50 \mu \mathrm{m}$ and a numerical aperture of $\mathrm{NA}=$ 0,06 demonstrated power reached of $8 \mathrm{~kW}$, where the parameter $\mathrm{M}^{2}$ was about four units. A further increase in power requires an increase in the diameter of the core and leads to a transition to a multi-mode regime. In existing fiber lasers with a power higher than $10 \mathrm{~kW}$, fiber-optic combination of radiation from several lasers is used. The resulting radiation is multimode, but it meets the requirements of industrial machinery for material processing.

If we consider the scheme of a high- power laser (Fig. 3), then it can be seen that the main elements of the laser are the fiber-optic radiation pump combiners, mode field adapters, cladding power strippers and fiber end caps.

When designing fiber-optic components, it is necessary to take into account a lot of details that ensure reliable operation of the elements in the conditions of high radiation power. For example, losses in

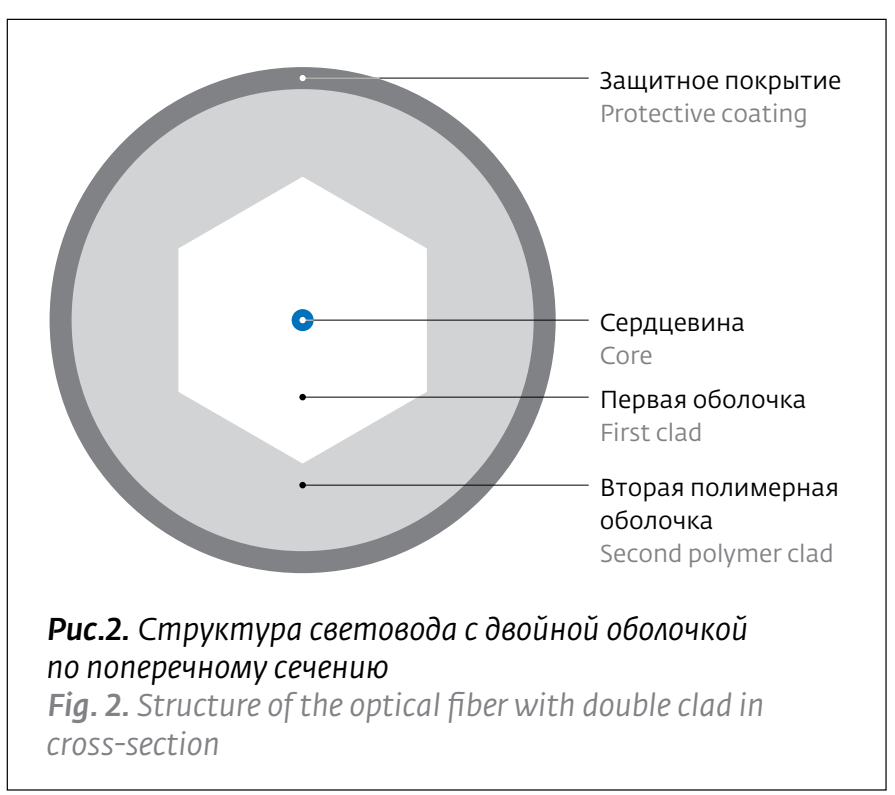




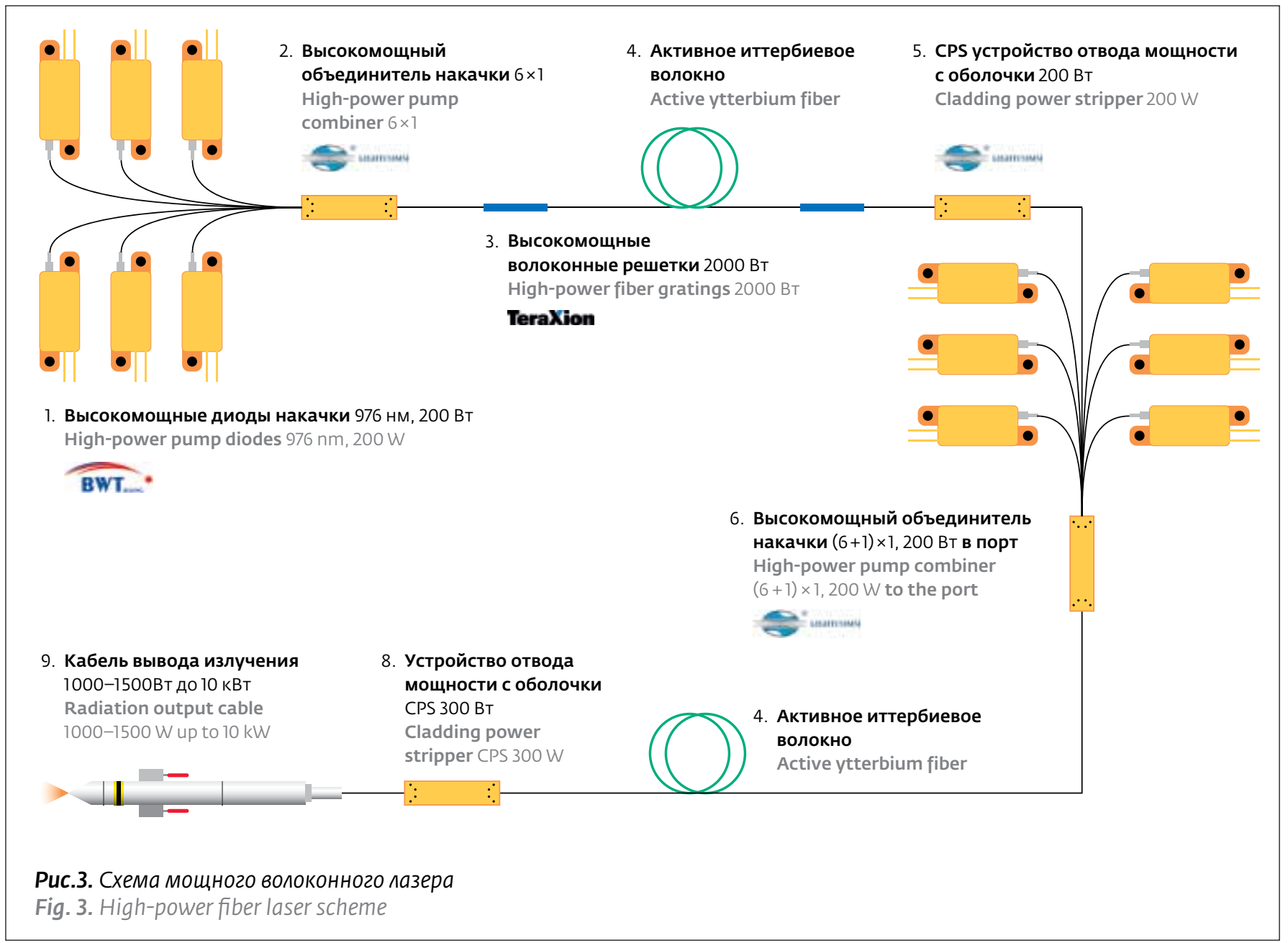

нескольких волоконных лазерных источников высокой мощности в одно волокно с общей суммарной мощностью 10 кВт и более. Структура схожа с объединителями накачки $\mathrm{N} \times 1$, разница заключается в том, что каждое волокно является сигнальным (рис.6).

\section{МЕТОДЫ РАСЧЕТА СПЛАВЛЕНИЯ ВОЛОКОН В ОБЪЕДИНИТЕЛЯХ}

В объединителях накачки типа $\mathrm{N} \times 1$ и $(\mathrm{N}+1) \times 1$ используется несколько многомодовых волокон, по которым распространяется излучение накачки. При изготовлении таких объединителей применяют технологию тейпирования, при которой волокна вытягиваются с уменьшением их диаметра и далее свариваются с соответствующим выходным волокном. Тейпирование характеризуется коэффициентом конусности (TR). Он определяется как отношение эффективного диаметра входного волокна к диаметру выходного. Под эффективным диаметром входного волокна принимается диаметр волокна, который дает components that are normally for telecommunications applications can lead to the destruction of a highpower laser system due to a strong overheating. As a rule, the most vulnerable element of a high-power fiber laser is the pump combiner, which provides for the input of pump radiation into the fiber.

This article deals with a one of the most important types of components used in fiber lasers - fiber combiners, used as the element base of fiber lasers and amplifiers. Fiber combiners can be divided into several types:

- pump combiners of $\mathrm{N} \times 1$ structure. Devices of this type combine multiple pump radiation sources into one fiber (Fig. 4).

- pump combiners with a central signal channel of the $(\mathrm{N}+1) \times 1$ structure. These devices combine several sources of pump radiation into one fiber, and additionally have a channel in the center into which a signal is fed for further amplification (Fig. 5).

- combiners of powerful signals of the $\mathrm{SN} \times 1$ structure. They are designed to combine several 

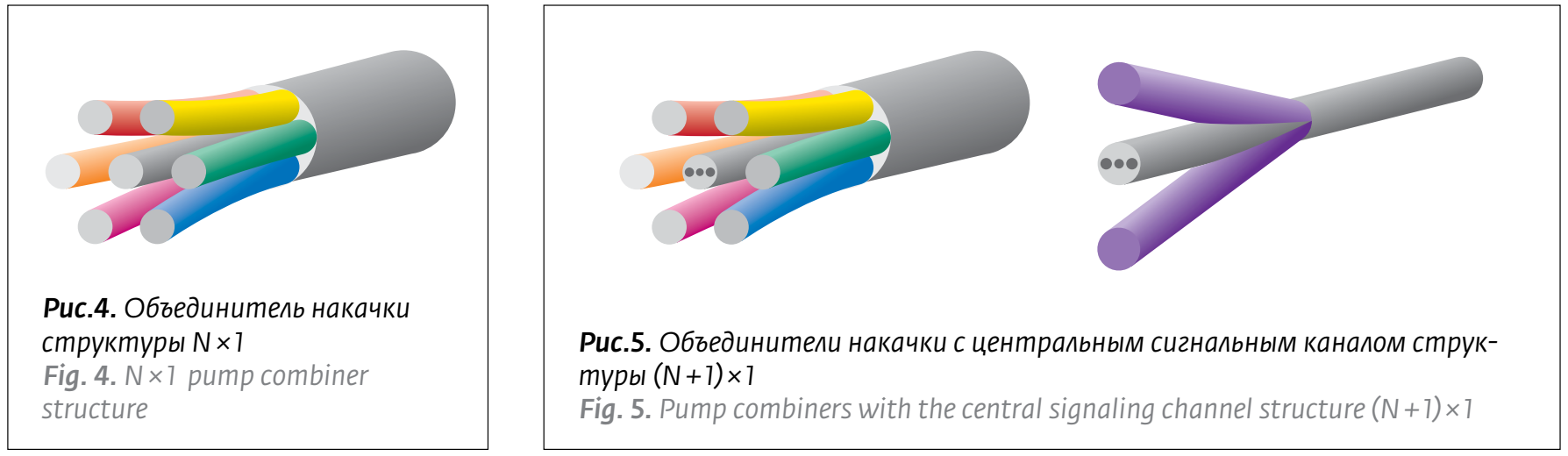

эквивалентную площадь поперечного сечения равную сумме площадей входных волокон.

Для исключения энергетических потерь при передаче светового сигнала в прямом направлении необходимо сохранить яркость луча. Согласование яркости луча входного (in) и выходного (out) волокон с соответствующими числовыми апертурами $\mathrm{NA}_{\text {in }}$ и $\mathrm{NA}_{\text {out }}$ выполняется из расчета, что коэффициент конусности (TR) удовлетворяет следующему условию:

$$
\mathrm{TR} \cdot \mathrm{NA}_{\text {in }} \leq \mathrm{NA} A_{\text {out }} \cdot
$$

На практике, для уменьшения потерь при сваривании волокон различных типов применяют геометрические и диффузионные тейперы (рис.7). Геометрические тейперы изготавливаются путем вытягивания волокна с большими геометрическими размерами, при этом диаметр оболочки и сердцевины изменяются линейно. Вытянутое до необходимого значения диаметра сердцевины волокно скалывается, после чего производится сварка. Диффузионные тейперы изготавливаются при нагревании волокна, в результате чего происходит диффузия легирующих добавок из сердцевины в оболочку. Диффузия приводит к увеличению диаметра сердцевины и к уменьшению разницы коэффициента преломления между материалами сердцевины и оболочки, что в свою очередь, приводит к увеличению диаметра поля моды. Скорость диффузии зависит от температуры, а также от химического состава матрицы сердцевины, содержащей элементы Ge, Al, F, редкоземельные элементы $\mathrm{Yb}, \mathrm{Er}, \mathrm{Tm}$ и т.д.

Для минимизации потерь и сохранения качества пучка важно учесть влияние переход- high-power fiber laser sources into a single fiber with a total power of $10 \mathrm{~kW}$ or more. The structure is similar to the Nxlpump combiners, the only difference being that each fiber is a signal one (Fig. 6).

\section{CALCULATION METHODS \\ OF FIBER FUSION IN THE COMBINERS}

In the pump combiners of the $\mathrm{N} \times 1$ and $(\mathrm{N}+1) \times 1$ multiple multimode fibers are used, which propagate the pump radiation. In the manufacture of such combiners, the tapering technology is used, when the fibers are drawn out with a decrease in their diameter and further are spliced to the corresponding output fiber. Tapering is characterized by a tapering coefficient (TR). It is defined as the ratio of the effective diameter of the input fiber to the diameter of the outlet one. Under the effective diameter of the input fiber, a fiber diameter is adopted which gives an equivalent cross-sectional area equal to the sum of the areas of the input fibers.

To avoid energy losses during the transmission of a light signal in the forward direction, it is necessary to preserve the brightness of the beam. Harmonization of the brightness of the input beam (in) and output (out) fibers with the corresponding numerical apertures $\mathrm{NA}_{\text {in }}$ and $\mathrm{NA}_{\text {out }}$ is carried out from the calculation that

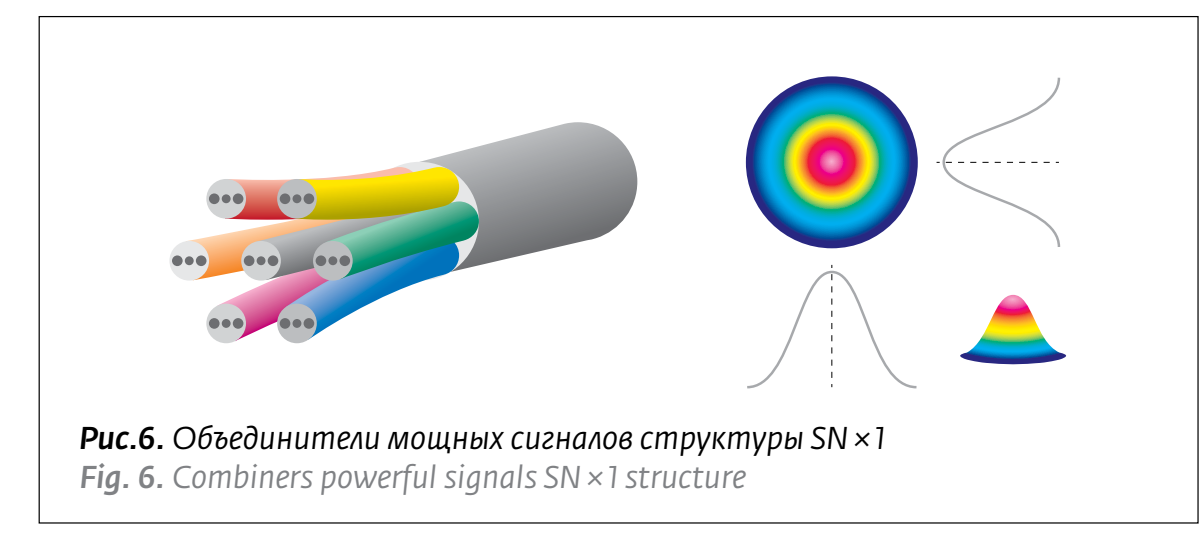


ных характеристик обоих видов тейпера. При определенной длине тейпера начинает выполняться условие адиабатического расширения, и фундаментальная мода распространяется без значительных потерь, связанных с возбуждением высших мод. Поэтому для волоконных объединителей область перехода моды должна быть адиабатической, а поле моды на выходе должно совпадать с полем моды выходного волокна.

Полное количественное описание распространения оптического поля через переходную область требует решения уравнений Максвелла с соответствующими граничными условиями на основе фактического волноводного свойства волокна и оптических характеристик переходной области. Когда излучение распространяется в сердцевине слабого волновода, то параметры поля в волокне определяются уравнением Гельмгольца [4]. Взаимодействие между полями в области перехода может быть описано теорией связанных мод. Эволюция поля представляет собой суперпозицию собственных мод $[5,6]$. В численном выражении уравнение Гельмгольца может быть решено методом распространения конечного луча с использованием коммерчески доступного программного обеспечения, например BeamProp Software [7] на основе оптических свойств волокна при соответствующих граничных условиях. Когда волокно подвергается термообработке, легирующая примесь в сердцевине диффундирует в оболочку, что приводит к изменению оптических свойств волокна. Диффузионные перемещения легирующих примесей в волокне можно рассчитать по закону Фика [8], предварительно учитывая распределение легирующей примеси в волокне перед диффузией.

Когда два волокна соединены друг с другом с помощью сварного соединения, в этом месте возникают потери при передаче излучения (transmission loss), которые могут появлятся из-за несогласованности поля мод свариваемых волокон или возникнуть в переходной области (transition loss). Потери в переходной области возникают, когда модовое преобразование происходит слишком быстро, т.е. по определению не является адиабатическим. Потери рассогласования мод могут быть оценены на основе интеграла перекрытия амплитуд полей волноводных мод с использованием следующего уравнения:

$$
\operatorname{Loss}(d B)=-10 \log _{10}\left[\iint \varphi_{A}(r, \theta) \cdot \varphi_{B}(r, \theta) \operatorname{drd} \theta\right]^{2}
$$

где $\varphi_{\mathrm{A}}(\mathrm{r}, \theta)$ и $\varphi_{\mathrm{B}}(\mathrm{r}, \theta)$ - нормированные амплитуды модовых полей для двух волокон А и В.

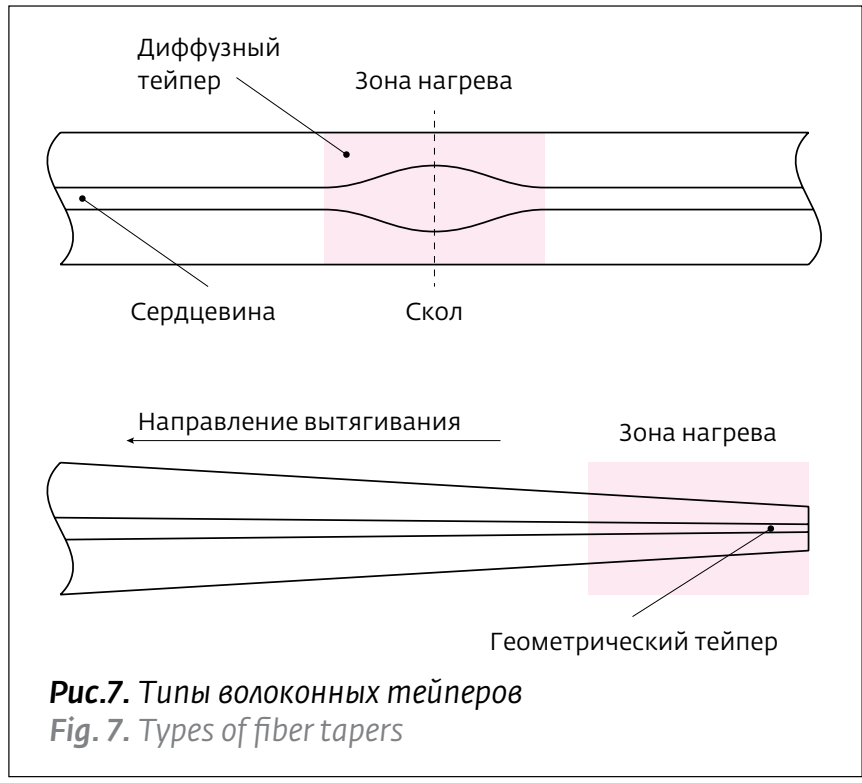

the tapering coefficient (TR) satisfies the following condition:

$$
\mathrm{TR} \cdot \mathrm{NA}_{\text {in }} \leq \mathrm{NA}_{\text {out }} \cdot
$$

In practice, to reduce losses when welding fibers of different types, geometric and diffusion tapers are used (Fig. 7). Geometric tapers those produced by drawing the fiber with large geometrical dimensions, the diameter of the core and cladding are changed linearly. The fiber drawn to the required core diameter is cleaved, after which splicing is performed. Diffusion tapers are produced when the fiber is heated, resulting in diffusion of dopants from the core to the clad. Diffusion leads to an increase in the diameter of the core and to a decrease in the difference in the refractive index between the materials of the core and the clad, which in turn leads to an increase in the diameter of the mode field. The diffusion rate depends on the temperature, as well as on the chemical composition of the core matrix containing the elements $\mathrm{Ge}, \mathrm{Al}, \mathrm{F}$, rare earth elements $\mathrm{Yb}, \mathrm{Er}$, Tm, etc.

To minimize losses and preserve the quality of the beam, it is important to take into account the effect of the transient characteristics both types of tapers. In certain taper length, the condition of adiabatic expansion is fulfilled, and the fundamental mode propagates without significant losses due to excitation of higher modes. Therefore, for fiber combiners, the frequency of the mode transition must be adiabatic, and the mode field at the output must coincide with the field of the mode of the output fiber. 
При согласовании модовых полей важно учитывать, что простое совпадение диаметров поля моды (MFD) вовсе не означает наличие нулевых потерь. Помимо этого должны совпадать формы модового поля, и переход моды должен быть адиабатическим, т.е. выполняться с минимальными потерями. В конечном счете, тщательный анализ распределения профиля показателя преломления вдоль длины соединения волокон определяет оптимальную связь мод.

Разберем подробнее метод согласования поля мод и яркости на примере объединителей накачки, выпускаемых компанией Lightcomm

При термическом расширении сердцевины, кроме ее диаметра и показателя преломления, также изменяется число мод, распространяющихся в волокне. А это означает, что после диффузии волокно из одномодового может превратиться в многомодовое. Но это утверждение не относится к методу сплавного биконического тейпирования (FBT - Fused Biconical Tapering). В этом случае показатель преломления и числовая апертура остаются неизменными, а следовательно, число распространяющихся мод остается неизменным - изменяется лишь диаметр сердцевины (рис.8).

Для волокна со ступенчатым профилем показателем преломления распределение профиля моды может быть определено аналитически. На рис.9 показано изменение диаметра поля моды излучения $(\lambda=1064$ нм) в зависимости от размера сердцевины для разных фиксированных значений числовой апертуры.

Для каждого значения числовой апертуры существует определенное значение диаметра сердцевины, при котором диаметр поля моды минимален. Любое дальнейшее уменьшение размера сердцевины вызывает фактически увеличение диаметра поля моды. Например, если волокно диаметром 400 мкм с сердцевиной 20 мкм и числовой апертурой 0,06 перетягивается в волокно с диаметром 125 мкм $(\mathrm{TR}=3,2)$, то диаметр сердцевины уменьшится до 6,25 мкм. А диаметр поля моды при этом будет оставаться приблизительно таким же, то есть 18 мкм (рис.10).

Важно отметить, что если два волокна имеют одинаковое значение диаметра поля моды, то это не всегда означает, что эти два волокна имеют идеальное согласование мод. Они могут иметь различные профили мод и, следовательно, вносить значительные потери, указанные в уравнении (2).

A complete quantitative description of the propagation of the optical field through the transition region requires the solution of Maxwell's equations with the corresponding boundary conditions based on the actual waveguide property of the fiber and the optical characteristics of the transition region. When the radiation propagates in the core of a weak waveguide, the parameters of the field in the fiber are determined by the Helmholtz equation [4]. The interaction between the fields in the transition region can be described by the theory of coupled modes. Evolution of a field is a superposition of the eigen modes [5, 6]. In numerical terms, the Helmholtz equation can be solved by a method of propagation of the finite beam using commercially available software, e.g., BeamProp Software [7] based on the optical properties of the fiber with the corresponding boundary conditions. When the fiber undergoes heat treatment, the dopant in the core diffuses into the clad, which leads to a change in the optical properties of the fiber. The dopant diffusion moves of the alloying impurities in the fiber can be calculated from the Fick law [8] taking into account the distribution of the dopant in the fiber before diffusion.

When the two fibers are connected to each other by splicing joint, there is a loss in transmission at this point (transmission loss), which can appear because of the inconsistency of the mode field of the fibers to be welded and whether arise in the transition region (transition loss). The loss in the transition region occurs when the mode conversion is too fast or, by definition, is not adiabatic. The loss and error modes can be estimated based on the overlap integral of the amplitudes of the waveguide mode fields using the following equation:

$$
\operatorname{Loss}(\mathrm{dB})=-10 \log _{10}\left[\iint \varphi_{A}(\mathrm{r}, \theta) \cdot \varphi_{\mathrm{B}}(\mathrm{r}, \theta) \mathrm{drd} \theta\right]^{2},
$$

where $\varphi_{A}(r, \theta)$ and $\varphi_{B}(r, \theta)$ are the normalized amplitudes of the mode fields for two fibers $A$ and $B$.

When negotiating the mode fields, is important to consider that just a coincidence of the mode field diameters (MFD) does not mean the presence of 


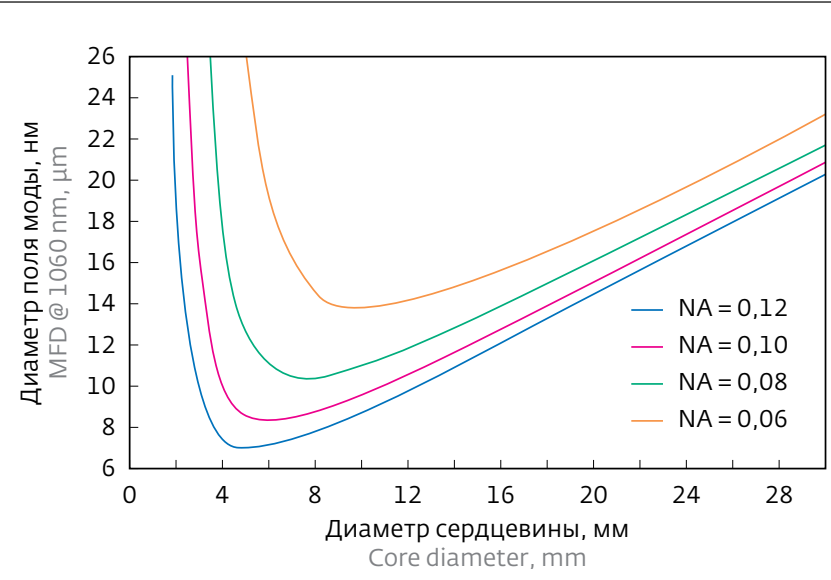

Pис.9. Зависимость изменения диаметра поля моды от размера сердцевины для фиксированных значений числовой апертуры [9]

Fig. 9. Dependence of the mode field diameter of the core size for a fixed value of the numerical aperture [9]

Необходимо тщательно контролировать тейпирование, чтобы оно происходило адиабатически. Общее эмпирическое правило гласит: для того чтобы не возбуждать моды более высокого порядка, наклон тейпера должен быть достаточно пологим, а его параметры ( $\mathrm{r}$-радиус сердцевины сужаемого волокна, $\beta_{1}$ и $\beta_{2}$ константы прохождения главной моды и мод высших порядков в сердцевине волокна) - соответствовать условию неравенства (3).

$$
\frac{\mathrm{dr}}{\mathrm{d} z}<\frac{\mathrm{r}}{2 \pi}\left(\beta_{1}-\beta_{2}\right) .
$$

Это означает, что для обеспечения перехода мод без потерь требуется определенная минимальная длина конуса. Большие длины конуса обеспечивают низкие потери, но их изготовление может потребовать сложной и громоздкой оснастки. Поэтому требуется оптимизировать длину тейпера. Чтобы оценить требуемую длину тейпера для разных волокон, используется программное обеспечение BeamProp [7] для расчета потерь. В моделировании тейпированное волокно имеет две секции: коническую и прямую. При расчете изменялась длина конической секции при заданном коэффициенте тейпирования (TR), а длина прямой секции во всех случаях составляла 5 мм. Результаты расчетов для обоих случаев (волокно № 1: $20 \mathrm{MKм/0,06}$ НА с ТR3 и волокно № 2: 10 мкм/0,08 NA с TR2) представлены на рис.8. Их анализ показал, что минимальная длина сужения должна составлять около 12 мм.
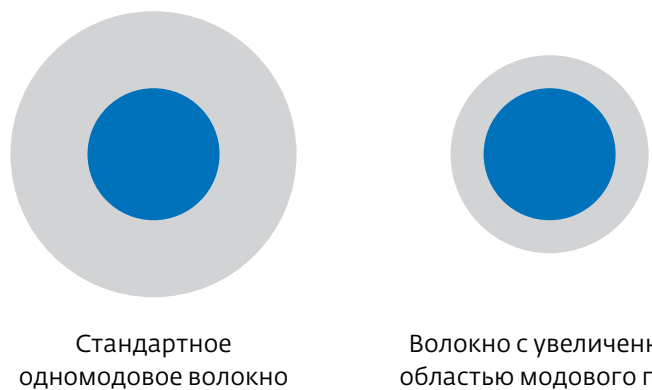

одномодовое волокно

Волокно с увеличенной областью модового поля

Pис.10. Сохранение диаметра поля моды при уменьшении диаметра

Fig. 10. Save mode field diameter with a decrease in diameter

zero-loss. Furthermore, the forms of the mode field must coincide, and the mode transition must be adiabatic, i.e. run with minimal loss. Ultimately, a thorough analysis of the distribution of the profile of the refractive index along the length of the fiber connection determines the optimal mode coupling.

Let us examine in more detail the method of matching the mode and brightness fields, using the example of pump-combiners by Lightcomm

When thermal expansion except of the core except for its diameter and the index of refraction, the number of mode propagating in the fiber also changes. And this means that, after diffusion, a single-mode fiber can turn into a multimode one. But this statement does not apply to the fused biconical tapering method (FBT). In this case, the refractive index and, accordingly, the numerical aperture remain unchanged, and therefore the number of propagating modes remains unchanged, where only the diameter of the core changes (Fig. 8).

For fibers with a stepped refractive index distribution profile mode can be determined analytically. Fig. 9 shows changes of the diameter a of the radiation mode field $(\lambda=1064 \mathrm{~nm})$, depending on the size of the core for different fixed values of the numerical aperture.

For each value of the numerical aperture there is a definite value of the diameter of the core, where the diameter of the mode field is minimum. Any further reduction of the core size is actually the increase in the mode field diameter. For example, if the fiber diameter of $400 \mu \mathrm{m}$ with a core of $20 \mu \mathrm{m}$ and a numerical aperture of 0,06 is dragged over in the fiber of diameter $125 \mu \mathrm{m}(\mathrm{TR}=3,2)$, then the core diameter will decrease to $6.25 \mu \mathrm{m}$. A mode field diameter thus will remain approximately the same, i.e. $18 \mu \mathrm{m}$ (Fig. 10). 
Кроме того, необходимо соблюдать аккуратность при проведении тейпированя. Иначе могут возникнуть потери на дефектах, макро- или микроизгибах, а это приведет к ухудшению качества выходного луча и к увеличению потерь.

\section{ОБЪЕДИНИТЕЛИ ВЫХОДНОГО СИГНАЛА}

Назначение объединителя выходного сигнала отличается от назначения объединителя накачки. Его задача - объединить несколько волоконных лазерных выводов (волоконных лазеров). Они могут быть объединены либо некогерентно - как объединение нескольких выходных волокон в одно волокно, или когерентно - путем согласования фазы каждого канала. В данной работе вопросы когерентного сложения излучения затрагиваться не будут.

В целом метод создания объединителей схож для всех типов и включает следующие шаги: соединение в жгут, тейпирование, скалывание и сварка.

Одним из наиболее удобных способов соединения волокон в жгут является использование кварцевых капилляров. Процесс соединения начинается с упаковки нужного числа волокон в капилляр с внутренним диаметром (ID) не меньше внешнего диаметра жгута волокон. В дальнейшем данный участок капилляра с волокном в оболочке будет конструкционным элементом объединителя. Рис.12 иллюстрирует эту концепцию на примере объединителя 7:1. На следующем шаге капилляр перетягивается с получением прямого участка внутреннего диаметра равного внешнему диаметру жгута волокон, очищенных от полимерной оболочки. Далее сами волокна очищаются от оболочки, про-

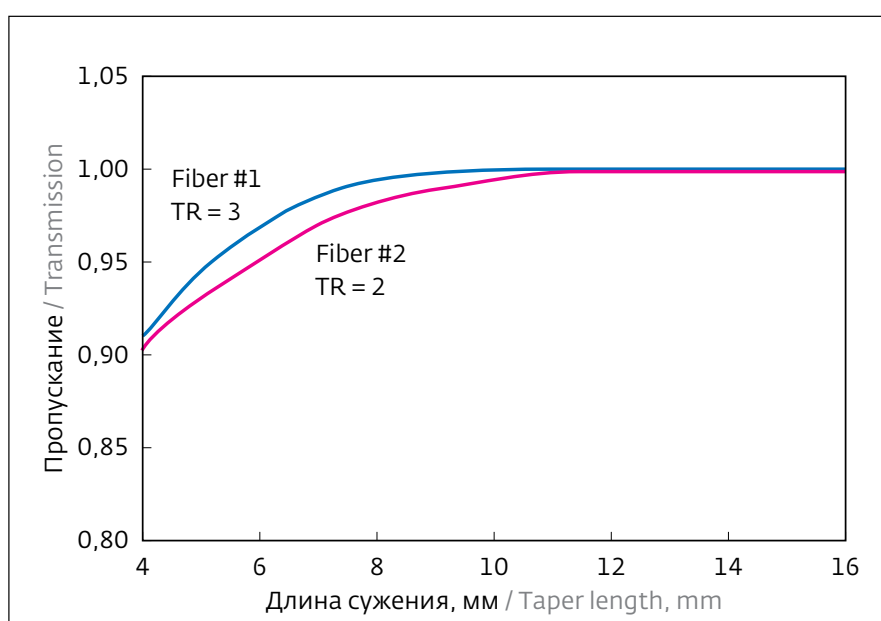

Puc.11. Потери на пропускание в зависимости от диины сужения [9]

Fig. 11. Loss in transmission depending on the restriction length [9]
It is important to note that if two fibers have the same value of the mode field diameter, this does not necessarily mean that these two fibers have the perfect coordination of events. They can have different mode profiles and therefore make a significant loss specified in the equation (2).

It is necessary to carefully control the tapering, so that it occurs adiabatically. The general rule of thumb is that in order not to excite higher-order modes, the taper pitch should be sufficiently flat, and its parameters ( $\mathrm{r}$ is the radius of the core of the fiber to be narrowed, $\beta_{1}$ and $\beta_{2}$ transmission constants of the main mode and higher order modes in the core of the fiber) shall correspond to the inequality condition (3).

$$
\frac{\mathrm{dr}}{\mathrm{dz}}<\frac{\mathrm{r}}{2 \pi}\left(\beta_{1}-\beta_{2}\right)
$$

This means that to ensure the transition of modes without losses, a certain minimum length of the taper is required. Large taper length provides low loss, but their manufacturing may require complicated and cumbersome equipment. Therefore, it is required to optimize the lengths of taper. To estimate the required length of the taper for different fibers, use
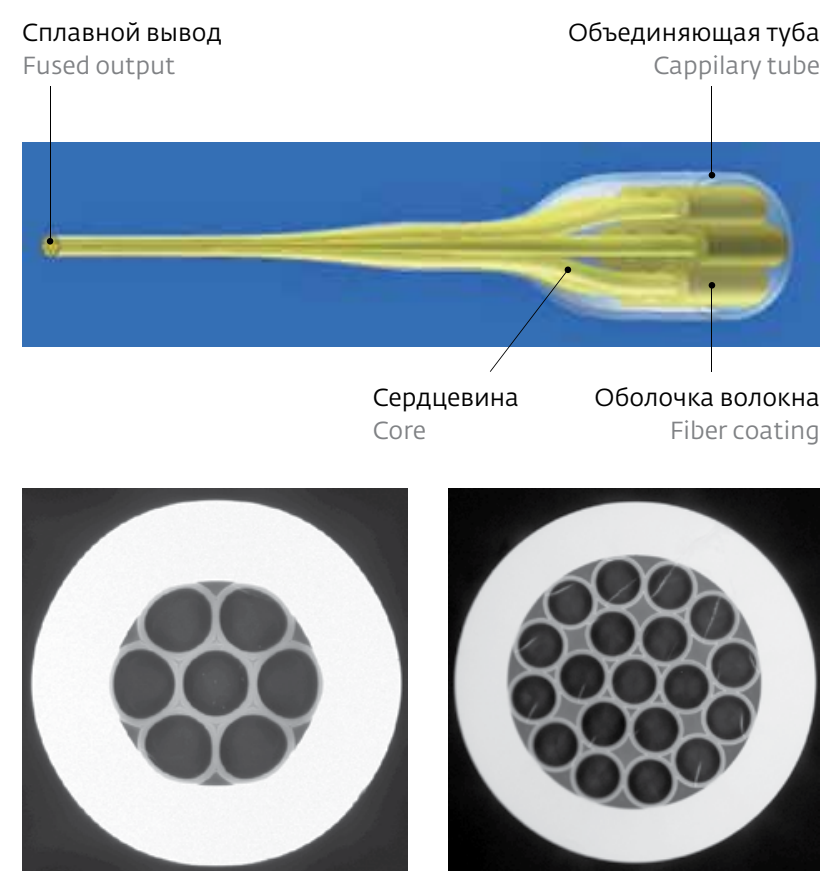

Puc.12. Схема сппавленного оптоволоконного объединителя $7 \times 1$ и 19 × 1 и вид торцов двух оптоволоконных объединителей [9]

Fig. 12. Scheme of fused fiber combiner $7 \times 1$ and $19 \times 1$ and form the ends of two fiber optic combiners [9] 

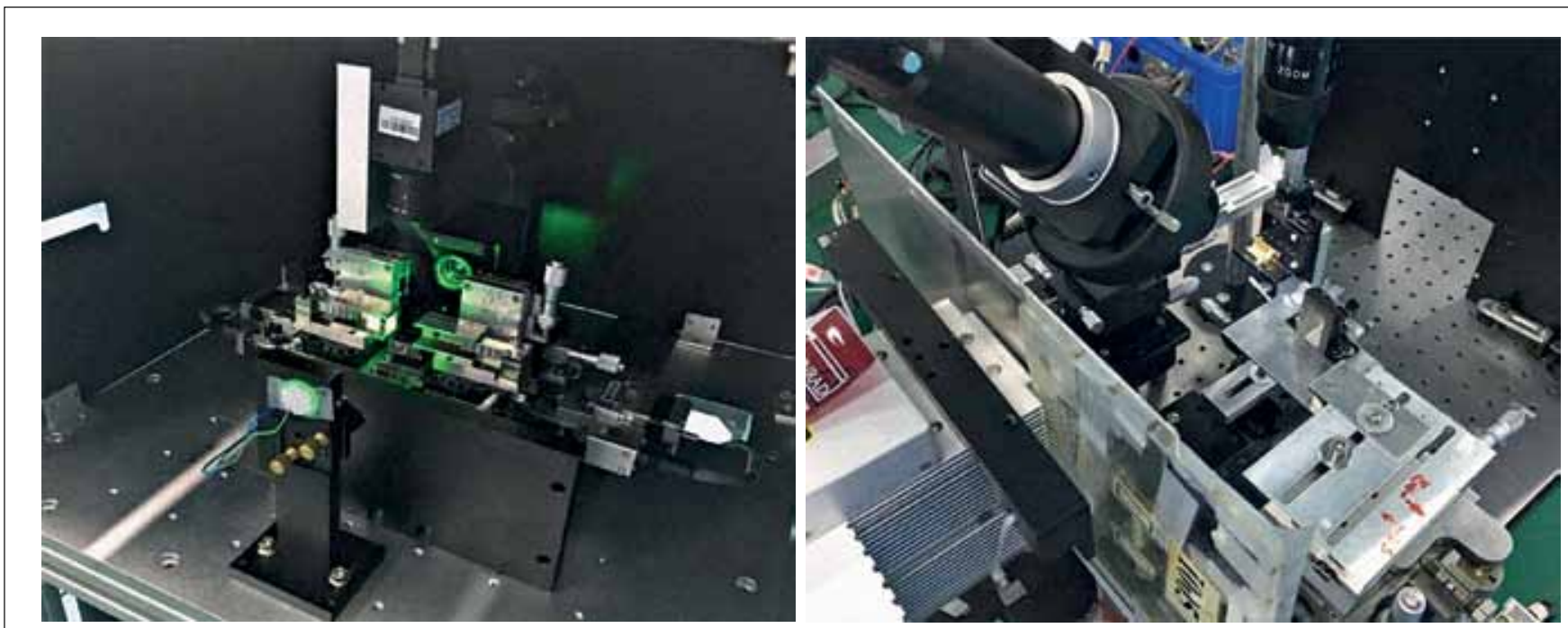

Puc.13. Лазерные установки для тейпирования и сварки волокон

Fig. 13. Laser installation for tapering and splicing

тираются и загружаются в подготовленный ранее капилляр. Если необходимо использовать сигналь ное волокно, то его следует на данном этапе устано вить строго в центре жгута. Волокна в капилляре в месте без оболочки перетягиваются до необходимого значения TR с нужной длиной конуса (адиабатический тейпер). Часто для удобства скалывания после тейпера добавляется небольшой прямой участок. Сколотый волоконный жгут приваривается к соответствующему выходному волокну с возможным модовым согласованием. В нижней части рис.12 представлены фотографии торцов оптоволоконных объединителей 7:1 и 19:1, созданных на установке Vitran GPX 3400.

Потери излучения в объединителях накачки должны быть минимальны (это ведет к минимальному нагреву объединителя). В таком случае температура нагрева зависит от корректного распределения числовой апертуры в зоне сужения. Если волокно или пучок волокон сужаются так, что нарушается закон полного внутреннего отражения, то происходит резкий рост потерь. Поэтому очень важно правильно рассчитать распределение числовой апертуры при сужении волокна. При этом необходимо минимизировать коэффициент конусности, а также уменьшить площадь "темного волокна". Под термином "темное волокно" имеют в виду любые области поперечного сечения, сквозь которые не проходит излучение,- оболочка волокна или капиллярная трубка. Для уменьшения таких потерь применя ется травление зон "темного волокна" фтористоводородной кислотой (HF). the BeamProp software [7] to calculate the losses. In the simulation the tapered fiber has two sections: a taper and a straight line. During the calculation, the length of the taper section was changed for a given tapering coefficient (TR), and the length of the straight section in all cases was $5 \mathrm{~mm}$. The results of the calculation for both cases (fiber No. 1: $20 \mathrm{~m} / 0.06 \mathrm{NA}$ TR3 and fiber No. 2: $10 \mu \mathrm{m} / 0.08 \mathrm{NA}$ with TR2) are shown in Fig. 8. Their analysis showed that the minimum length of constriction should be about $12 \mathrm{~mm}$.

Furthermore, care must be taken when conducting tapering. Otherwise, you may experience losses due to defects, macro- or micro-bending, and this will lead to worsening quality of the output beam and to loss increase.

\section{SIGNAL COMBINERS}

The purpose of the output signal combiner is different from the purpose of the pump combiner. Its task is to combine several fiber laser outputs (fiber lasers). They can be combined either incoherently, as the union of several output fibers into one fiber, or coherently, by matching the phase of each channel. In this paper, the questions of coherent addition of radiation will not be considered.

In general, the method of creating combiners is similar for all types and includes the following steps: combining in a bundle, tapering, stripping and splicing.

One of the most convenient ways of combining fibers in a bundle is the use of quartz capillaries. The joining process begins with the packing of the 
Немаловажную роль играют установки, на которых выполняется тейпирование и сварка волокон. Существуют установки с дуговой, тепловой и лазерной сваркой. Сказать, какие установки лучше, а какие нет, однозначно нельзя. Но заметно, что все большей популярностью пользуются лазерные установки (рис.13).

\section{ЗАКЛЮЧЕНИЕ}

В заключение подчеркнем основные моменты проектирования и производства высокомощных волоконных объединителей. Высокомощные волоконные объединители накачки компании "Lightcomm" разработаны на базе технологии сплавного биконического тейпирования (FBT - Fused Biconical Tapering) волокна.

При изготовлении высокомощных волоконных объединителей накачки с сигнальным каналом модовое поле входного и выходного сигнальных волокон определяется первоначально, затем рассчитывается распределение мощности излучения фундаментальной моды по длине перехода. При этом интеграл перекрытия модовых полей двух волокон (формула 2) должен стремиться к единице. Таким образом минимизируются вносимые потери.

Диаметр пятна поля моды выбирается в зависимости от диаметра сердцевины волокна в соответствии с седловидной кривой (см. рис.9).

Исходя из сопоставления диаметров пятен поля моды между входом и выходом, вычисляется соответствующий размер сердцевины волокна.

Согласование яркости вычисляется в зависимости от соотношения диаметра сердцевины входного волокна (а), количества входных волокон (N), выходного диаметра (b) и числовой апертуры входного и выходного волокон $\left(\mathrm{NA}_{\mathrm{a}}, \mathrm{NA}_{\mathrm{b}}\right)$. После вычисления необходимых параметров волокна подвергаются высокотемпературной обработке.

Заключительным этапом в изготовлении высокомощных объединителей накачки является производство корпуса с эффективным отводом тепла (рис.15). В зависимости от мощности и структуры объединителя корпуса отличаются по габаритным размерам, т. к. чем выше температура нагрева, тем больше должна быть длина для температурной диссипации. Таким образом, передовые технологии производства позволяют работать с мощностями около $10 \mathrm{kBT}$, что является абсолютным рекордом. Ежемесячно компанией Lightcomm производится более 7000 единиц продукции. Существуют различные вариации структуры объединителей, такие как $\mathrm{N} \times 1,(\mathrm{~N}+1) \times 1$, есть версии с сохранением поля- desired number of fibers into a capillary with an internal diameter (ID) of not less than the outer diameter of the fiber bundle. In the future, this part of the capillary with the fiber in the clad will be the structural element of the combiner. Fig. 12 illustrates this concept using the example of a $7: 1$ combiner. In the next step, the capillary is drawn to obtain a straight portion of the inner diameter equal to the outer diameter of the fiber bundle cleaned from the polymeric clad. Further, the fibers themselves are cleaned of the clad, wiped and loaded into a previously prepared capillary. If it is necessary to use a signal fiber, then at this stage it shall be installed strictly in the center of the bundle. Fibers in the capillary in a place without a clad are dragged to the required value of TR with the required length of the taper (adiabatic taper). Often, for ease of cleavage, a small straight line is added after the taper. The discarded fiber bundle is welded to the corresponding output fiber with possible modulation matching. The lower part of Fig. 12 shows photographs of fiber combiner ends $7: 1$ and 19:1 created on installation Vitran GPX 3400.

The losses in the pump combiners should be minimal (this leads to minimum heating at the combiner). In this case, the heating temperature depends on the correct distribution of the numerical aperture in the tappering zone. If the fiber or fiber bundle narrows so that the law of total internal reflection is violated, then a sharp increase in losses occurs. Therefore, it is very important to correctly calculate the distribution of numerical aperture when the fiber is tapered. In this case, it is necessary to minimize the tapering coefficient, and also to reduce the area of "dark fiber". The "dark fiber" is any cross-sectional area through which radiation does not pass: a fiber clad or a capillary tube. To reduce these losses, dark fiber zones are etched with hydrofluoric acid (HF).

An important role is played by installations where tapering and fiber splicing is performed. There are installations with arc, heat and laser splicing. It is hard to say which of the are better ones, but laser apparatuses are much more popular (Fig. 13).

\section{CONCLUSION}

In conclusion we would like to emphasize the main points of design and production of high-power fiber combiners. High power pump combiners of "Lightcomm" are developed on the basis of the fused biconical tappering technology (FBT).

When manufacturing high-power fiber pumping combiners with a signal channel, the mode field of the input and output signal fibers is determined initially, 


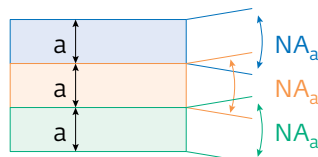

Профиль входных волокон

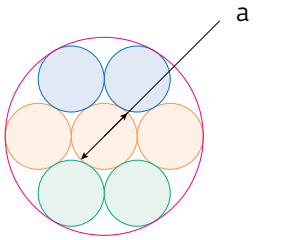

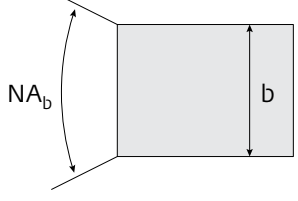

Выходной профиль

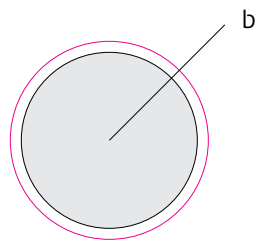

Puс.14. Cоотношение диаметров и числовых апертур входных и выходного волокна

Fig. 14. Ratio of the diameters and numerical apertures of the input and output fiber

ризации, количество объединяемых волокон может достигать 61.

На данный момент наиболее востребованными структурами являются $7 \times 1,19 \times 1,(6+1) \times 1$ и $(18+1) \times 1$ (см. рис.12), т. к. именно при таком количестве волокон достигается максимальная плотность объединения, а следовательно, увеличивается эффективность накачки. Такие структуры, как $37 \times 1$, $(36+1) \times 1$ и $(60+1) \times 1$, используются редко, ввиду их не самой высокой экономической эффективности (совокупность уровня выходной мощности, стоимости самого объединителя и всех лазерных диодов измеряется в количестве единиц долларов на ватт). Они востребованы в основном в военной промышленности или в исследовательских институтах. Структуры $(1+1) \times 1$ и $(2+1) \times 1$ используются в маломощных

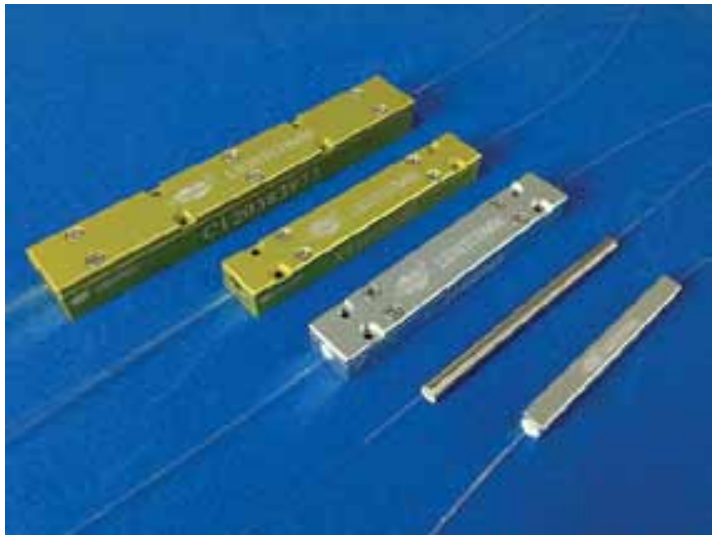

Puс.15. Объединители в корпусах с эффективным отводом тепиа

Fig. 15. Packages with effective heat dissipation

and then the distribution of the fundamental mode radiation power along the transition length is calculated. In this case, the overlap integral of the mode fields of two fibers (formula 2) should tend to unity. Thus, the insertion losses are minimized.

The diameter of the spot of the mode field is chosen depending on the diameter of the fiber core in accordance with the saddle curve (see Fig. 9).

Based on the diameter comparison of the mode field between input and output, the corresponding fiber core size is calculated.

The brightness matching is calculated depending on the ratio of the core diameter of the input fiber (a), the number of input fibers $(\mathrm{N})$, the output diameter $(\mathrm{b})$ and the numerical aperture of the input and output fibers $\left(\mathrm{NA}_{\mathrm{a}}, \mathrm{NA}_{\mathrm{b}}\right)$. After calculating the necessary

Таблица 1. Типы объединителей накачки структуры $(\mathrm{N}+1) \times 1$

Table 1. Types of pump combiners of $(\mathrm{N}+1) \times 1$ structure

\begin{tabular}{|c|c|c|c|c|}
\hline $\begin{array}{l}\text { Структура } \\
\text { Structure }\end{array}$ & $\begin{array}{l}\text { Волокно накачки } \\
\text { Pump fiber }\end{array}$ & $\begin{array}{c}\text { Волокно входного сигнала } \\
\text { Signal fiber }\end{array}$ & $\begin{array}{l}\text { Выходное волокно } \\
\text { Output fiber }\end{array}$ & $\begin{array}{l}\text { Допустимая мощность, Вт/порт } \\
\text { Permissible power, watts/port }\end{array}$ \\
\hline$(2+1) \times 1$ & $200 / 2200.22 \mathrm{NA}$ & 20/400 DCF & 20/400 DCF & 500 \\
\hline$(6+1) \times 1$ & $200 / 2200.22 \mathrm{NA}$ & $\begin{array}{c}\text { 20/400 DCF } \\
\text { (или 30/250 DCF) }\end{array}$ & $\begin{array}{c}\text { 20/400 DCF } \\
\text { (или 30/600 DCF) }\end{array}$ & 1000 \\
\hline$(6+1) \times 1$ & $300 / 3300.22 N A$ & $30 / 400 \mathrm{DCF}$ & $50 / 800 \mathrm{DCF}$ & 1300 \\
\hline$(6+1) \times 1$ & $200 / 2200.22 N A$ & 20/400 DCF & 20/250 DCF & 500 \\
\hline$(18+1) \times 1$ & $\begin{array}{c}105 / 1250.15 \mathrm{NA} \\
(\text { или 106.5/125 0.22NA) }\end{array}$ & SMF-28e & $14 / 250 \mathrm{DCF}$ & 200 \\
\hline$(60+1) \times 1$ & $\begin{array}{c}105 / 1250.15 \mathrm{NA} \\
\text { (или 106.5/125 0.22NA) }\end{array}$ & 10/130 DCF & $30 / 600$ DCF & 140 \\
\hline
\end{tabular}




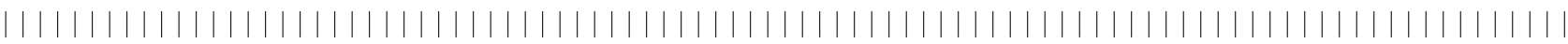

Таблица 2. Спецификация объединителя накачки $(6+1) \times 1$

Table 2. Specification of pump combiner $(6+7) \times 1$

\begin{tabular}{|c|c|c|c|c|c|}
\hline \multicolumn{2}{|c|}{$\begin{array}{l}\text { Параметры/Условия эксплуатации } \\
\text { Parameters/Operating Conditions }\end{array}$} & $\begin{array}{l}\text { Мин. } \\
\text { Min }\end{array}$ & $\begin{array}{l}\text { Tип. } \\
\text { Type }\end{array}$ & $\begin{array}{r}\text { Макс. } \\
\operatorname{Max}\end{array}$ & $\begin{array}{l}\text { Примечания } \\
\text { Notes }\end{array}$ \\
\hline \multicolumn{2}{|c|}{$\begin{array}{l}\text { Длина волны сигнала, нм } \\
\text { Signal wavelength, nm }\end{array}$} & 1000 & 1064 & 1100 & - \\
\hline \multicolumn{2}{|c|}{$\begin{array}{l}\text { Длина волны накачки, нм } \\
\text { Pump wavelength, nm }\end{array}$} & 800 & - & 1000 & - \\
\hline \multirow{3}{*}{$\begin{array}{l}\text { Волокно } \\
\text { накачки } \\
\text { Pump fiber }\end{array}$} & $\begin{array}{l}\text { Диаметр сердцевины, мкм } \\
\text { Core diameter, } \mu \mathrm{m}\end{array}$ & - & 200 & 220 & \multirow{3}{*}{$\begin{array}{c}\text { Обратитесь к кодам волокон: } \\
\text { "140": 200/220 0.22NA } \\
\text { "143": 220/242 0.22NA } \\
\text { Refer to the fiber codes: } \\
\text { "140": 200/220 0.22NA } \\
\text { "143": } 220 / 2420.22 \mathrm{NA}\end{array}$} \\
\hline & $\begin{array}{l}\text { Диаметр оболочки, мкм } \\
\text { Cladding diameter, } \mu \text { m }\end{array}$ & - & 220 & 242 & \\
\hline & $\begin{array}{l}\text { Числовая апертура } \\
\text { Numerical aperture }\end{array}$ & - & 0,22 & - & \\
\hline \multicolumn{2}{|c|}{$\begin{array}{l}\text { Сигнальное волокно } \\
\text { Signal fiber }\end{array}$} & \multicolumn{3}{|c|}{$\begin{array}{l}x / 250 \text { SCF(DCF) } \\
x / 400 \text { DCF }\end{array}$} & $x=20,25, \ldots *$ \\
\hline \multicolumn{2}{|c|}{$\begin{array}{l}\text { Выходное волокно } \\
\text { Output fiber }\end{array}$} & \multicolumn{3}{|c|}{$\begin{array}{l}20 / 400 \mathrm{DCF} \\
25 / 400 \mathrm{DCF}\end{array}$} & - \\
\hline \multicolumn{2}{|c|}{$\begin{array}{l}\text { Эффективность накачки, \% } \\
\text { Pumping efficiency, \% }\end{array}$} & 95 & 98 & - & - \\
\hline \multicolumn{2}{|c|}{$\begin{array}{l}\text { Сигнальные потери, дБ } \\
\text { Signal loss, dB }\end{array}$} & - & 0,4 & 0,5 & - \\
\hline \multicolumn{2}{|c|}{$\begin{array}{l}\text { Мощность, Вт } \\
\text { Power, W }\end{array}$} & - & - & 200 & $\begin{array}{l}\text { Каждый порт } \\
\text { Each port }\end{array}$ \\
\hline \multicolumn{2}{|l|}{$M^{2}$} & - & 1,1 & 1,3 & - \\
\hline \multicolumn{2}{|c|}{$\begin{array}{l}\text { Обратные оптические потери, дБ } \\
\text { Return losses, dB }\end{array}$} & 40 & - & - & - \\
\hline \multicolumn{2}{|c|}{$\begin{array}{l}\text { Оптическая изоляция, дБ } \\
\text { Optical isolation, dB }\end{array}$} & 20 & - & - & - \\
\hline \multicolumn{2}{|c|}{$\begin{array}{l}\text { Длина волокна, м } \\
\text { Fiber length, m }\end{array}$} & 0,8 & - & - & $\begin{array}{l}\text { Каждый порт } \\
\text { Each port }\end{array}$ \\
\hline \multicolumn{2}{|c|}{$\begin{array}{l}\text { Рабочая температура эксплуатации, }{ }^{\circ} \mathrm{C} \\
\text { Operating temperature, }{ }^{\circ} \mathrm{C}\end{array}$} & -5 & - & 70 & \\
\hline \multicolumn{2}{|c|}{$\begin{array}{l}\text { Рабочая влажность, \% отн. влажность } \\
\text { Operating humidity, \% rel. humidity }\end{array}$} & 5 & - & 95 & $\begin{array}{l}\text { Не рекомендуется использовать в условиях высо- } \\
\text { кой влажности долгое время } \\
\text { It is not recommended to use in high humidity } \\
\text { conditions for a long time }\end{array}$ \\
\hline \multicolumn{2}{|c|}{$\begin{array}{l}\text { Температура хранения, }{ }^{\circ} \mathrm{C} \\
\text { Storage temperature, }{ }^{\circ} \mathrm{C}\end{array}$} & -40 & - & - & - \\
\hline \multicolumn{2}{|l|}{$\begin{array}{l}\text { Корпус } \\
\text { Package }\end{array}$} & \multicolumn{3}{|c|}{$C 7^{* * n}$} & - \\
\hline
\end{tabular}

Диаметр сердцевины входного/сигнального волокна должен быть меньше или эквивалентен диаметру сердцевины выходного волокна / The diameter of the input/signal fiber core should be less than or equivalent to the output fiber core diameter

** Корпус С7. Габаритные размеры составляют $100 \times 15 \times 10$ мм / Casing C7. Overall dimensions are $100 \times 15 \times 10 \mathrm{~mm}$. 
импульсных лазерных системах, например MOРАлазерах или лазерах с модуляцией добротности.

В табл. 1 приведены основные типы объединителей накачки структуры $(\mathrm{N}+1) \times 1$. В табл. 2 представлены характеристики наиболее часто используемого объединителя накачки $(6+1) \times 1$.

Волоконно-оптические системы развиваются стремительно, и все больше отраслей применяют их в качестве технологических решений. Правильный подбор компонентов обеспечит не только длительный срок службы, но и стабиль ность системы. Как известно, лидером в производстве оптоволоконных лазеров и систем на их основе является IPG Photonics. Следует отметить, что достичь успеха в сфере производства лазеров и лазерных систем можно благодаря наличию собственной элементной базы и унификации решений. Таким образом, Lightcomm обеспечивает необходимые потребности в оптоволоконных элементах для создания волоконных лазеров до $10 \mathrm{kBT}$ в маломодовом режиме и менее мощных - в одно модовом. Применение специальных волоконных объединителей сигнала открывает возможности достижения мощности свыше 10 кВт для промышленных применений. Успех в создании модулей накачки компаний ВWT и II VI Laser Enterprise покрывает потребность в источниках накачки. Также в Китае есть производители оптоволокна и собственно самих лазеров и систем, кооперация которых открывает для потребителей новые возможности.

\section{ЛИТЕРАТУРА}

1. Huan Zhan, Qinyong Liu, Yuying Wang, Weiwei Ke, Li Ni, Xiaolong Wang, Kun Peng, Cong Gao, Yuwei Li, Honghuan Lin, Jianjun Wang, Feng Jing,

Aoxiang Lin. 5kW GTWave fiber amplifier directly pumped by commercial $976 \mathrm{~nm}$ laser diodes. - Optics Express, 28 November, 2016, v.24, is.24.

2. [www.ipgphotonics.com]. IPG Photonics successfully tests world's first 10 kilowatt single-mode production laser. - IPC Photonics, June 15, 2009.

3. Oiang Fang, Jinhui Li, Wei Shi, Yuguo Qin, Yangxu, Xiangjie Meng, Robert A. Norwood, Nasser Peyghambarian. 5 kW Near-Diffraction-Limited and 8 kW High-Brightness Monolithic Continuous Wave Fiber Lasers Directly Pumped by Laser Diodes. - IEEE Photonics Journal, Oct. 2017, v.9, is.5.

4. M.Born, E.Wolf. Principles of Optics, 6-Ed. - Cambridge University Press, 1999.

5. D. Marcuse. Mode conversion in optical fibers with monotonically increasing core radius. - J. Lightwave Technol., 1987, LT-5, p.125.

6. A. R. Nelson. Coupling of optical waveguides by taper. - Appl. Opt., 1975, v.14, p.3012.

7. BeamProp Software.-RSoft Design Group.

8. A. F. Mills. Heat and Mass Transfer. - Richard Irwin Inc., Concord, MA, 1995.

9. Baishi Wang, Eric Mies. Review of Fabrication Techniques for Fused Fiber Components for Fiber Lasers. - Proc. 7195 of SPIE, 2009. parameters, the fibers undergo high-temperature processing.

The final stage in the manufacture of high-power pump combinators is the production of a casing with efficient heat dissipation (Fig. 1-5). Depending on the power and structure of the combiner, the packages differ in overall dimensions, because the higher the heating temperature, the greater the length of the thermal dissipation. Therefore, advanced production technology allows to work with a power of about $10 \mathrm{~kW}$, which is an absolute record. Every month, Lightcomm produces more than 7,000 units. There are different variations of combiners structures such as $\mathrm{N} \times 1,(\mathrm{~N}+1) \times 1$, there are versions of polarizationmaintaining amount united fibers 61 can reach.

Are currently the most popular structures $7 \times 1$, $19 \times 1,(6+1) \times 1$ and $(18+1) \times 1$ (see. Fig. 12), as these are the numbers of the fibers help to achieve maximum combining density and, consequently, increasing pump efficiency. Such structures as $37 \times 1,(36+1) \times 1$ and $(60+1) \times 1$ are rarely used, because of not very high economic efficiency (the set output power level, the cost of the combiner and all the laser diodes is measured in the number of dollars per watt), mainly in the military industry or research institutes. Structures $(1+1) \times 1$ and $(2+1) \times 1$ are used in low-power pulsed laser systems, e.g. MORA lasers or Q-switched lasers.

Table. 1 shows the main types of pump structures combiners $(\mathrm{N}+1) \times 1$. Table. 2 shows the characteristics of the most commonly used pump combiner $(6+1) \times 1$.

Fiber optic systems are developing rapidly, and more and more industries are applying them as technological solutions. Proper selection of components will not only ensure a long service life, but also the stability of the system. As is well known leader in the production of fiber-optic lasers and systems based on them is IPG Photonics. It should be noted that to achieve success in the field of production of lasers and laser systems can be by providing their own element base and unify solutions. Thus, Lightcomm provides required in optical elements needs to create fiber lasers to $10 \mathrm{~kW}$ in single-mode and less powerful in few-mode regime. The use of special fiber signal combiners opens up the possibility of achieving in excess of $10 \mathrm{~kW}$ power for industrial applications. Success in creating pumping modules companies BWT and II VI Laser Enterprise covers the need for the pump sources. Also, in China, there are manufacturers of fiber lasers themselves and the actual and systems, co-operation which has opened up new opportunities for consumers. 